\title{
Incidence of intramammary infections during the dry period without or with antibiotic treatment in dairy cows - a quantitative analysis of published data
}

\author{
Aurélie RoBerT ${ }^{\mathrm{a}, \mathrm{b} *}$, Henri SEEGERS ${ }^{\mathrm{a}}$, Nathalie BAREILLE ${ }^{\mathrm{a}}$ \\ ${ }^{a}$ Unit of Animal Health Management, ENVN/INRA, BP 40706, Nantes Cedex 03, France \\ ${ }^{b}$ ARILAIT Recherches, 42 rue de Châteaudun, 75314 Paris Cedex 09, France
}

(Received 17 September 2004; accepted 1 July 2005)

\begin{abstract}
The study was aimed at summarising the literature that compares the incidence levels of spontaneously occurring intramammary infections (IMI) during the dry period, without versus with antibiotic dry cow treatment (DCT). A meta-analytic relative risk (RR) calculation was implemented when a priori relevant. Two main categories of comparison were used in the 36 selected papers. In the first category, the udder quarters were randomly allocated (at quarter or cow level) to an untreated or a treated group. Quarter incidence averaged $12.8 \%$ (weighted mean) in untreated quarters, and depending on the DCT used, from 6.6 to $8.0 \%$ in treated quarters. The meta-analytic RR of new IMI for untreated versus treated quarters varied from 1.54 to 1.94 , depending on the DCT used. DCT was mainly found effective against IMI due to streptococci and coagulase-positive staphylococci. Based on only a few papers, the application of an internal teat sealer was associated to a quite similar (or possibly better) protection against IMI than DCT, but only in a subpopulation of particular (selected) cows. In the second category of studies, a selective dry cow or quarter antibiotic-treatment (selective DCT or DQT), according to cow or quarter selection criteria, was compared to blanket DCT. The meta-analytic RR of new IMI was 1.71 for selective DCT versus blanket DCT. Selective DQT seemed to be more at risk than selective DCT, but consisted of treating a much lower proportion of quarters. The summary-results provided by our meta-analysis should only be used with caution, due to possibly low external validity. More research seems to be relevant on the risk factors of new IMI during the dry period to make the outcomes of omission of DCT in selected cows more predictable under field conditions.
\end{abstract}

dairy cow / mastitis / risk / dry-cow treatment / meta-analysis

\section{INTRODUCTION}

The dry period (cessation of regular milking) in the dairy cow is a sensitive period for the occurrence of new intramammary infections (IMI), especially shortly after dryingoff and before calving [50]. Since the 1960s, in order to control the risk of new IMI after drying-off, and also to try to eliminate existing IMI, a blanket dry cow antibiotic treatment (blanket DCT) has been recommended at drying-off for all cows, as a component of the "5 Points Mastitis Control Plan" [19, 36, 49, 51]. Blanket DCT is today widely implemented, with an adoption rate ranging from 75 to $99 \%$ depending

\footnotetext{
* Corresponding author: arobert@ vet-nantes.fr
} 
on the country [17], except in the Nordic European countries ${ }^{1}$.

Blanket DCT has been challenged for a long time by some researchers, holding that only infected cows must be treated $[17,21$, $25,38,72]$ or due to its high cost [87]. More recently, blanket DCT has again become more challenged in several countries for multiple reasons. The first one is the consumers and society's expectations regarding antibiotic residues in milk, or antibiotic resistance $[3,4,8,10]$. The DCT is, reportedly, a possible vector of pathogens inducing a new IMI, under certain circumstances $[23,81]$. Moreover, the systematic use of DCT at drying-off possibly seems no longer necessary, in view of the reduction of the prevalence of udder-born contagious pathogens, as shown by the improvement in SCC levels in almost all countries during the last 20 years [33, 41, 64].

An alternative, to the strictly preventive use of DCT, is to apply an internal, or external teat sealer ${ }^{2}[3,4,27,35,42,44,45,46$, $73,88]$. These sealers can be used in combination with DCT to obtain a preventive and a curative effect $[26,45,46,47,68,84]$. Another alternative to blanket DCT is selective DCT. In this strategy, only cows or quarters assumed infected are treated. Selection of quarters treated can be done at the cow level or at the quarter level.

In most countries, these alternative strategies are not yet widespread. One explanation could be the fact that their economic outcomes for dairy farmers are not wellknown or predictable. To allow economic calculations to compare strategies for DCT (e.g. blanket DCT versus complete omission or selective DCT, or use of a teat sealer alone or in combination), information is

\footnotetext{
1 Ekman T., Osteras O., Mastitis control and dry cow therapy in the Nordic countries, Proc. Annual Meeting National Mastitis Council, Lansing, Michigan, USA, 2003, pp. 18-30.

2 Timms L.L., Efficacy of barrier teat dips in preventing dry period mastitis, in: Smith K.L. (Ed.), NMC, Proc. National Mastitis Council Regional Meeting, Syracuse, NY, USA, 1997, pp. 10-17.
}

needed about their curative and preventive effectiveness. The curative effectiveness of blanket DCT, or another strategy is usually quite well-known or assumed, compared to its preventive effectiveness, which remains less predictable. In fact, the magnitude of the preventive effect depends widely on the risk of new IMI. Currently, in many herds, this risk has been widely reduced by better management and hygiene during the dry period $[5,17,33,71,72]$ and consequently, one may only expect a small resulting preventive effect, even with a very effective DCT. Relevant knowledge on the risk of new IMI and on its preventable fraction by DCT (or application of a teat sealer) is thus critical for decision making.

Some review papers have already been published on mastitis control during the dry period and a large number of original studies on the risk of new IMI during the dry period have been conducted $[5,10,22,32$, 71]. However, no study has provided a quantitative overview of the differences in incidence with or without DCT, nor a discussion of variation in these differences. Therefore, the purpose of this paper was to provide a quantitative comparative analysis of the incidence of spontaneously occurring IMI during the dry period, with or without DCT (random or selective omission, with or without application of a teat sealer).

\section{MATERIALS AND METHODS}

\subsection{Materials for meta-analysis}

\subsubsection{Selection of papers}

A search in the literature was conducted using the Commonwealth Abstract Bulletin (CAB) database for papers indexed since 1990, Medline for papers indexed since 1966, and OldMedline for articles indexed from 1957 to 1965 . Research terms consisted of combined descriptors of the disease, the population under study and the period in question: (Mastitis or mammary gland disease or intramammary infection or udder 
infection or intramammary pathogen or udder pathogen) and (dairy cows or dairy cattle) and (late lactation or lactation end or dry cow or selective dry cow therapy or systematic dry cow therapy or selective dry cow treatment or systematic dry cow treatment or antibiotherapy or antibiotic or dry period or drying-off or pre-partum or parturition or post-partum or early lactation). Only papers published in English, French, German, Italian or Spanish were considered. At this stage, the references cited in all papers found were also taken into account. The papers had to fulfil the following conditions:

(i) To be an original study (review or symposium papers were cited but not included in the quantitative analyses). Moreover, if several studies had been made using the same study sample and method, only the study with the most detailed description of materials and methods was kept.

(ii) To report the incidence of spontaneous IMI cases during the dry period in field conditions. Routes and infective doses of experimentally induced IMI were not considered as being fully representative of IMI under field conditions.

(iii) The status of quarters regarding IMI had to be determined based on microbiological examinations of aseptic quarter milk samples.

A total of 36 papers based on 30 studies were included. Some authors presented the results of several protocols in the same paper (for easier reading, each protocol was numbered in roman numerals [5-I, 5-II, 59-I, 59-IV]). Others presented results from the same protocol in several papers (for easier reading, studies on the same protocol were grouped [3-4, 10-11, 63-64-65, 66-74, 76-77, 78-79]).

The aspects of study sample and design likely to influence external validity of the results were systematically checked and recorded by the same abstractor. The description focused on the following: country, study period, type of herds (experimental or commercial), number of herds/cows/quarters, method of drying-off, selection of herds/ cows, active-principle in the DCT used, milk sampling timing, microbiological procedure, definition of an infected quarter, definition of a new IMI, prevalence of IMI at dryingoff and type of pathogen involved, number of quarters at risk contracting a new IMI during the dry period. All these data are displayed in Tables I, II and III, and in Section 2.1.2.

\subsubsection{Study design in selected papers}

\subsubsection{Study sample}

The study samples in the selected papers included from 1 to 140 herds (mainly less than 10 herds) and from 40 to 3987 cows (mainly around 200-250 cows) (Tab. I). All studies were done at the quarter level as the observation unit.

\subsubsection{Type of comparison implemented}

Firstly, the effect of a random total omission of antibiotic DCT was assessed. Such studies compared cows from the same herd randomly assigned in two groups: a group of untreated cows and a group of treated cows (type 1a in Fig. 1) [5-I, 5-II, 14, 22, $24,30,31,32,34,57,58,66-74,67,75,76-$ $77,78-79,80,82,83]$. In order to account for individual factors likely to influence the incidence of IMI, some authors made an intra-cow comparison (type 1b in Fig. 1): in each cow, some quarters were treated and some were left untreated. Depending on the study, quarters were either randomly assigned [48, 59-I, 88] or a fixed half udder was treated or not [59-IV, 71]. The same study designs (1a or 1b) were used to compare the application of a teat sealer to DCT $[35,88]$ or to the absence of any DCT [3-4, 88]. However, these study designs were applied here to a selected sample of cows or quarters, presumed not infected or infected at a low prevalence level (see Tab. I).

Secondly, the effect of selective DCT strategies was assessed. Studies compared cows from the same herd randomly assigned into two groups: selectively treated versus 
Table I. Study samples in selected studies (sorted by year of publication).

\begin{tabular}{|c|c|c|c|c|}
\hline Reference & Country ${ }^{a}$ & $\begin{array}{l}\text { Number of herds } \\
\text { (type)/Number of } \\
\text { cows }{ }^{b}\end{array}$ & $\begin{array}{l}\text { Method of } \\
\text { drying-off }\end{array}$ & Inclusion criteria $^{\mathrm{c}}$ \\
\hline [76-77] & $\mathrm{ZA}$ & $35(\mathrm{C}) / 888$ & na & Not stated \\
\hline [59-I] & IE & $6(\mathrm{na}) / 146$ & A & New infection only for uninfected quarters \\
\hline [59-IV] & IE & $1(\mathrm{C}) / 75$ & A & New infection only for uninfected quarters \\
\hline [67] & IL & $1(\mathrm{C}) / 79$ & A & Not stated \\
\hline [22] & US & 5 (E) / 222 & na & Not stated \\
\hline [32] & US & $\mathrm{na}(\mathrm{E} C) / 964$ & na & Not stated \\
\hline [75] & US & $1(\mathrm{E}) / 172$ & na & $\begin{array}{l}\text { Cows uninfected at drying-off except by Micrococci, } \\
\text { diphtheroids, Staphylococcus epidermis }\end{array}$ \\
\hline [48] & US & $5(\mathrm{C}) / 252$ & na & Not stated \\
\hline [66-74] & FR & $1(\mathrm{E}) / 190$ & na & Not stated \\
\hline [31] & US & $18(\mathrm{C}) / 273$ & na & Not stated \\
\hline [62] & US & $1(\mathrm{E}) / 232$ & na & Not stated \\
\hline [82] & US & 75 (C) / 1318 & A & $\begin{array}{l}\text { High prevalence of staphylococcal and streptococcal } \\
\text { infections; } C \text {. bovis considered as not pathogen }\end{array}$ \\
\hline [24] & US & 141 (C) / 3987 & na & Not stated \\
\hline [57] & $\mathrm{NZ}$ & $6(\mathrm{C}) / 330$ & na & Not stated \\
\hline [58] & NZ & 7 (C) / 120 & na & Not stated \\
\hline [63-64-65] & GB & $6(\mathrm{C}) / 930$ & na & $\begin{array}{l}\text { Herds with BSCC }<500000 \mathrm{c} / \mathrm{mL} \text {, with }<15 \% \text { of } \\
\text { quarters infected by a MP, and free from St. agalactiae }\end{array}$ \\
\hline [78-79] & US & $1(\mathrm{E}) / 43$ & A & $\begin{array}{c}\text { Herd with }<1 \% \text { of quarters infected by CPS and } \\
\text { St. agalactiae }\end{array}$ \\
\hline [30] & US & $1(\mathrm{E}) / 140$ & na & Not stated \\
\hline [14] & US & $1(\mathrm{E}) / 80$ & na & Not stated \\
\hline [10-11] & $\mathrm{AU}$ & 12 (C) / 1044 & na & $\begin{array}{c}\text { Herds with } 100000<\text { BSCC }<400000 \mathrm{c} / \mathrm{mL} \text {; cows } \\
\text { infected in less than } 3 \text { quarters; new infection only for } \\
\text { uninfected quarters }\end{array}$ \\
\hline [80] & IL & $1(\mathrm{C}) / 106$ & na & $\begin{array}{l}\text { Herd with BSCC }=619000 \mathrm{c} / \mathrm{mL} \text {; new infection only } \\
\text { for uninfected quarters }\end{array}$ \\
\hline [71] & NL & $1(\mathrm{E}) / 68$ & I & $\begin{array}{c}\text { Herd with } \mathrm{BSCC}=140000 \mathrm{c} / \mathrm{mL} \text {, with }<5 \% \text { of } \\
\text { quarters infected by a MP }\end{array}$ \\
\hline [34] & US & $4(\mathrm{C}) / 185$ & A & $\begin{array}{l}\text { Herds with } 170000<\mathrm{BSCC}<250000 \mathrm{c} / \mathrm{mL} \text {; new } \\
\text { infection only for uninfected quarters }\end{array}$ \\
\hline [86] & NZ & $4(\mathrm{E} \mathrm{C}) / 371$ & I & New infection only for uninfected quarters \\
\hline [88] & $\mathrm{NZ}$ & $3(\mathrm{C}) / 528$ & na & $\begin{array}{c}\text { Cows with ISCC }<200000 \mathrm{c} / \mathrm{mL} \text {, with at least } 3 \\
\text { uninfected quarters at drying-off }\end{array}$ \\
\hline [3-4] & GB & $\begin{array}{l}2(\mathrm{E}) / 170 \\
5(\mathrm{C}) / 231\end{array}$ & A & $\begin{array}{l}\text { Herds with } 115000<\mathrm{BSCC}<350000 \mathrm{c} / \mathrm{mL} \text {; cows } \\
\text { with ISCC }<200000 \mathrm{c} / \mathrm{mL} \text {, with no clinical case }\end{array}$ \\
\hline$[5-\mathrm{I}]$ & GB & $2(\mathrm{E}) / 236$ & A & $\begin{array}{l}\text { Herds with } \mathrm{BSCC}=150000 \mathrm{c} / \mathrm{mL} \text {; cows uninfected at } \\
\text { drying-off except by CNS or Corynebacterium species }\end{array}$ \\
\hline [5-II] & GB & $2(\mathrm{C}) / 76$ & A & $\begin{array}{c}\text { Herds with } \mathrm{BSCC}=250000 \mathrm{c} / \mathrm{mL} \text {; cows with variety } \\
\text { of infections at drying-off }\end{array}$ \\
\hline [35] & GB & $16(\mathrm{C}) / 467$ & na & $\begin{array}{l}\text { Herds with BSCC }<200000 \mathrm{c} / \mathrm{mL} ; \text { cows with } \mathrm{ISCC}< \\
\qquad 200000 \mathrm{c} / \mathrm{mL} \text {, no clinical case }\end{array}$ \\
\hline [83] & AR & $1(\mathrm{E}) / 44$ & na & Cows with no infection with MP at drying-off \\
\hline
\end{tabular}

${ }^{a}$ International abbreviation of the country; ${ }^{\mathrm{b}}(\mathrm{C})$ : commercial; (E): experimental ${ }^{\mathrm{c}} \mathrm{A}$ : abrupt, I: intermittent, na: not available; ${ }^{\mathrm{d}} \mathrm{CNS}$ : coagulase-negative staphylococci, CPS: coagulase-positive staphylococci, c/mL: cells by millilitre, ISCC: individual somatic cell count, BSCC: bulk tank milk somatic cell count, MP: major pathogens, C. bovis: Corynebacterium bovis, St. agalactiae: Streptococcus agalactiae. 
Table II. Elements of materials and methods used in selected studies (sorted by year of publication).

\begin{tabular}{|c|c|c|}
\hline Reference & Active principle of DCT (in $\mathrm{mg} /$ tube $)^{\mathrm{a}}$ & $\begin{array}{l}\text { Pathogens included in the calculation } \\
\text { of the incidence }{ }^{\mathrm{b}}\end{array}$ \\
\hline [76-77] & CP- 1) Clox (200-LA) / EP- 2) Clox (1000-LA) & S. au / St. ag, dy, ub \\
\hline [59-I] & CP $(\mathbf{Q T})-$ Pen $(300)$ & CPS / St. ub, dys \\
\hline [59-IV] & CP (QT) -Clox (500-LA) & CPS / St. ub, dys / Other \\
\hline [67] & CP-Clox (500) & S. au / St. ag \\
\hline [22] & CP- Pen $\left(2.10^{5-\mathrm{I}} \mathrm{U}\right)+\mathrm{DHS}$ (1000-na) & S. au/ St. ag, sp / Cf \\
\hline [32] & $\mathbf{C P}-$ Clox $(500)$ & na \\
\hline [75] & EP-Clox (500-na) & S. au / St. sp / Other \\
\hline [48] & EP- Novo (600)+Pen (5 10 $0^{5-I}$ U-LA) & na \\
\hline [66-74] & CP - Clox (500) / EP - Pen (106 IU)+DHS (1000) & na \\
\hline [31] & $\begin{array}{c}\text { EP-Novo(400)+Pen }\left(10^{5}, 2.10^{5}, 4.10^{5-\mathrm{I} U-n a)} /\right. \\
\text { Novo(400, } 600-\text {-na }) / \text { Pen }\left(10^{5}, 2.10^{5}, 4.10^{5-\mathrm{I}} \mathrm{U}-\mathrm{na}\right)\end{array}$ & S. au / St. ag, sp / Other cocci \\
\hline [62] & CP-Pen $\left(10^{6}\right.$ IU $)+$ DHS (1000-LA) & S. au / St. ag, S. sp / Cf / Mixed \\
\hline [82] & $\begin{array}{c}\text { EP- Novo (1) 50-LA, 2) 200-LA, 3) 400-LA, 4) } \\
\text { 600-LA) }\end{array}$ & S. au / St. ag, sp \\
\hline [24] & $\begin{array}{c}\text { EP- 1) Pen }\left(10^{6} \text { IU }\right)+\text { DHS (1000-na) / 2) Clox (500) } \\
\text { / 3) 4) 5) Novo+Pen (du) }\end{array}$ & S. sp / St. ag, sp / Cf \\
\hline [57] & CP- 1) Neo (500) + Pen (325.000IU-na) / 2) Clox & S. au, ep / St. ag, ub, sp \\
\hline [58] & CP-Pen $\left(2.10^{5-\mathrm{I}} \mathrm{U}\right)+$ Novo $(400)$ & S. au, ep / St. ag, ub, sp \\
\hline [63-64-65] & CP- Pen $\left(10^{6} \mathrm{IU}\right)+\mathrm{DHS}(500-\mathrm{LA}) /$ Clox $(500)$ & S. au / St. ub / Cf \\
\hline [78-79] & CP-Novo (du) & St. sp / Cf \\
\hline [30] & $\begin{array}{c}\text { CP- 1) Novo (400-na) / 2) Cephp (300-na) / 3) Pen } \\
\left(10^{6} I U\right)+D H S(1000-n a)\end{array}$ & S. au, CN / St. sp / Cf / C. b / other \\
\hline [14] & CP-Clox $(500)-1) 1$ injection / 2) 3 injections & S. CN, CP / St. sp / C. sp / Ba / Ps / Ye \\
\hline [10-11] & CP-Clox (500) & S. au / St. ub / other \\
\hline [80] & $\begin{array}{l}\text { CP- 1) Norfloxacin (subcutaneous) / 2) } \\
\text { Oxytetracyclin (intramuscularly) / 3) Cephp (500-na) }\end{array}$ & S. au \\
\hline [71] & $\begin{array}{c}\text { CP }\left(\mathbf{Q T}^{\mathbf{T}}\right)-\operatorname{Pen}\left(10^{6} \mathrm{IU}\right)+\mathrm{DHS}(100)+\text { nafcillin } \\
(100-\mathrm{LA})\end{array}$ & $\begin{array}{c}\text { S. au, CN / St. ub, dy, sp / Cf / A. p / } \\
\text { Ent / Ps }\end{array}$ \\
\hline [34] & CP-Cephp (300) & S. au, sp / St. sp / Cf / C. b \\
\hline [86] & $\mathbf{C P}-\mathrm{Ce}$ & S. au, CN/ St. l \\
\hline [88] & $\begin{array}{c}\text { CP (QT)- Teat Sealer / Cephl (250-LA) / Teat sealer } \\
+ \text { Clox }(600)\end{array}$ & S. au, CN/ St. sp. / Cf / other \\
\hline [3-4] & CP- Teat Sealer & S. au / St. ub, dy / Cf / \\
\hline [5] & CP-Cephl (250-LA) / Clox (600-LA) & S. au / St. ub, dy / Cf / A. sp / Mixed \\
\hline [35] & CP- Teat Sealer / Cephl (250-LA) & $\begin{array}{c}\text { S. au, CN / St. ub, dy, sp / Cf / A. p / } \\
\text { Ent / Ps }\end{array}$ \\
\hline [83] & NA - Spiramycin + DHS (intramuscularly) & S.au / St. ub, dy \\
\hline
\end{tabular}

a CP: commercial preparation; EP: experimental preparation; NA: information about type of preparation not available; Cephl: cephalonium; Clox: cloxacillin; Neo: neomycin; Pen: penicillin; Novo: novobiocin; DHS: dihydrostreptomycin; Cephp: cephapirin; (du: dose unknown; quantity of active principle in $\mathrm{mg}-$ LA: long acting ointment base; na: base ointment not available; when nothing is specified it means short acting base ointment);

${ }^{\mathrm{b}}$ S.: Staphylococcus (au: aureus, CN: coagulase negative, CP: coagulase positive, ep: epidermis, sp: species); St.: Streptococcus (ag: agalactiae, (ag): S. ag excluded, dy: dysgalactiae, gr: green (uberis, dysgalactiae, group D), sp: species, ub: uberis); C: Corynebacterium (b: bovis, sp: species); Ye: Yeast; Cf: Coliform; Ent: Enterobacteriaceae (E. c: Escherichia coli), Ba: Bacillus species, Ps: Pseudomonas sp; A. p: Arcanobacterium pyogenes; na: identification not made available. 
A. Robert et al.

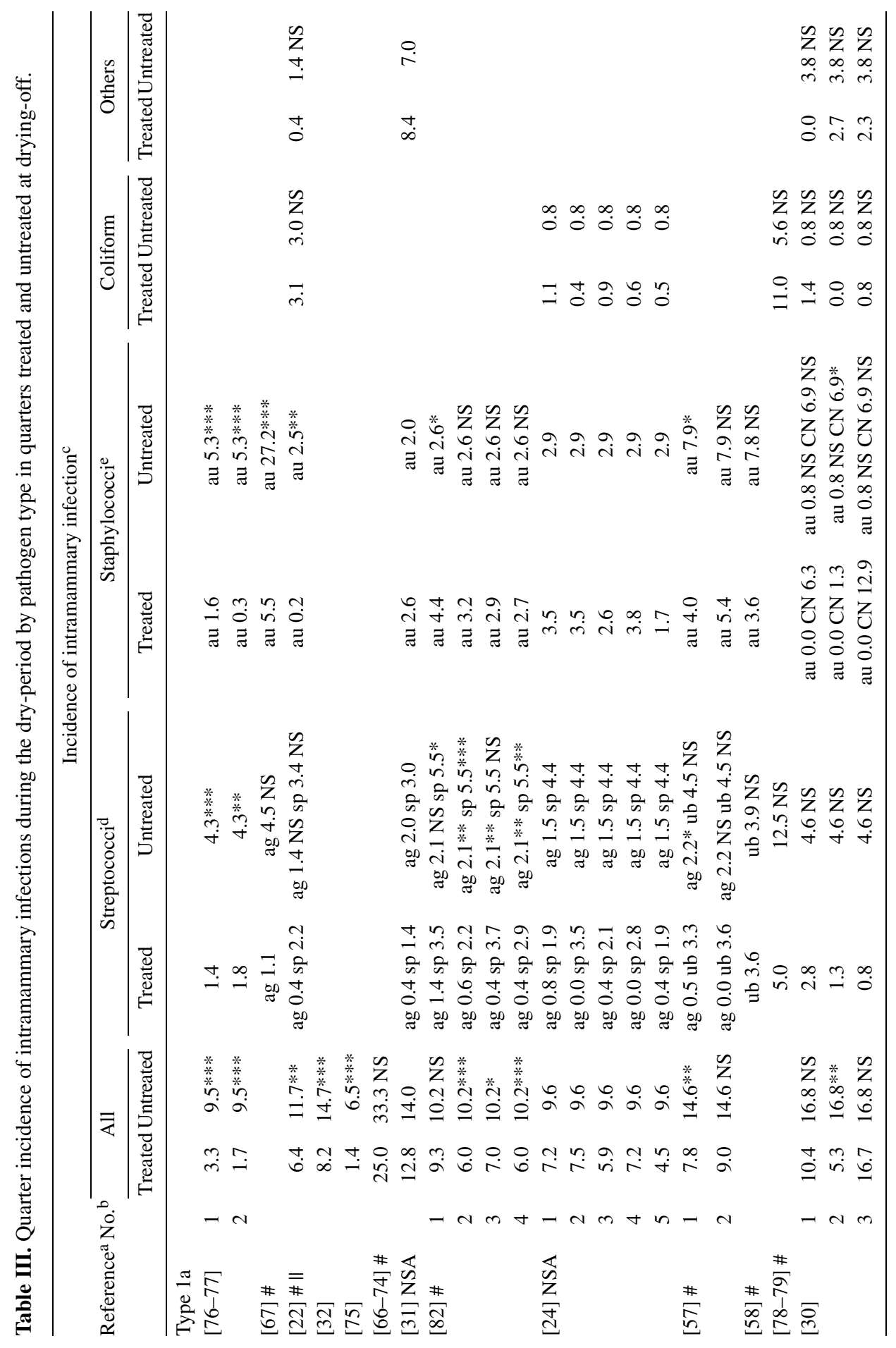




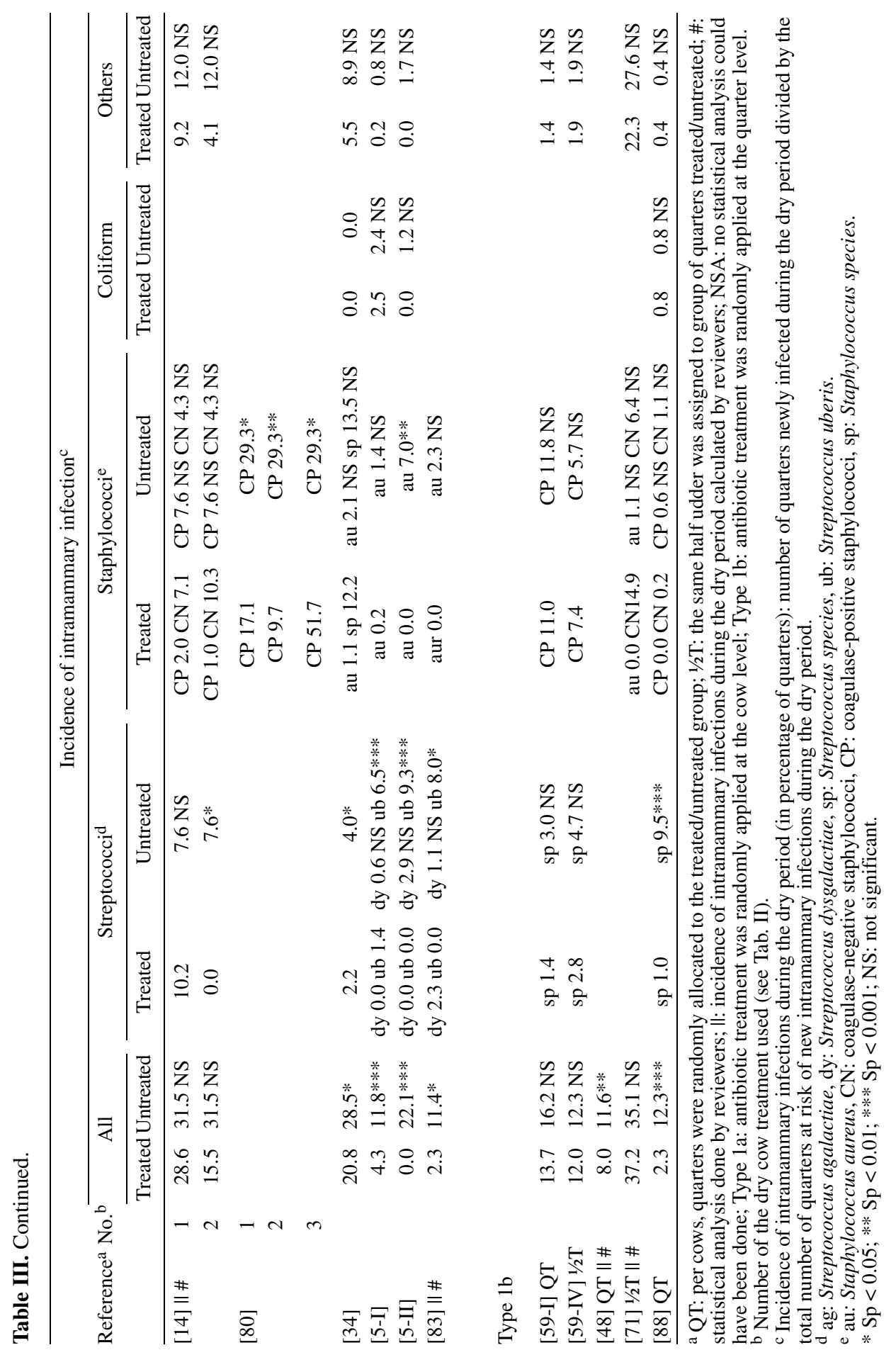



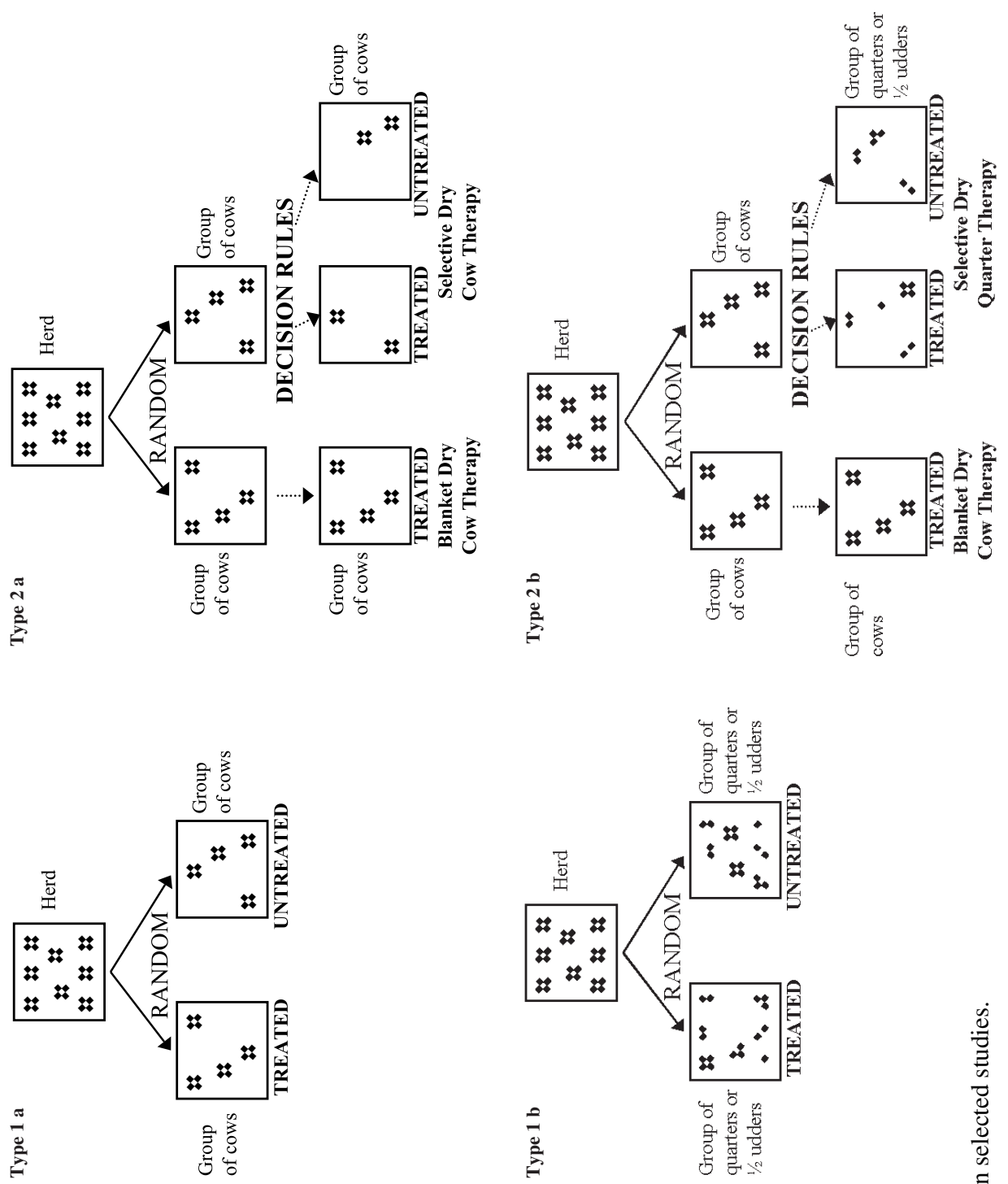
blanket DCT. The selective treatment could be applied at two levels: at the cow level (selective DCT) for type 2a in Figure 1 [10$11,62,66-74,86]$ and at the quarter level (selective DQT) for type 2b in Figure 1 [1011, 63-64-65, 86]. The selection criteria of cows or quarters treated were based on microbiological examination [10-11, 6364-65, 86] or on the SCC level and/or the Californian mastitis test score [62, 66-74].

\subsubsection{Milk sampling for bacteriological examination}

In all selected studies, samples were taken at drying-off and shortly after calving, to assess the possible change in quarter infection status during the dry period. In 24 studies, two (or more) consecutive samples (at a few days interval) [3-4, 5-I, 5-II, 10-11, 22, 62, 66-74, 75, 78-79] or two (or more) duplicate samples (at the same time) $[14,24,31,32,34,35,57,58,67,71,76-$ $77,82,83,86,88]$ were taken. In one study, some additional samples were taken along the dry period, to better assess the timing of the occurrence of new IMI [78-79].

\subsubsection{Bacteriological procedure}

The two standard procedures mostly used were instituted by the National Mastitis Council [14, 22, 24, 30, 57, 58, 62, 78$79,82]$ or by the International Dairy Federation [3-4, 5-I, 5-II]. Some other authors used a personal procedure derived from the previous ones. Methodological issues which could impair the sensitivity or specificity of the bacteriological procedures were checked: the volume of milk spread over a fixed area [12], the storage of samples, especially the freezing of samples $[39,70]$, and the type of growth medium used (selective medium or not).

\subsubsection{Antibiotic treatment}

This paper was not aimed at summarising the curative effectiveness of DCT. The pharmacokinetic properties of the ointment base were therefore not considered. Most DCT were intramammary-labelled drugs (for details see Tab. II), except in [80] and [83], where some DCT were administered intramuscularly or subcutaneously. The molecules used were specified only to explain possible discrepancies among the studies. In the selected studies, some molecules with a wide spectrum of activity on Gram+ and Gram- pathogens [5-I, 22, 24, 30, 34, $35,48,57,58,59-\mathrm{I}, 62$, 63-64-65, 66-74, $71,80,83,86,88]$, and also other molecules only active on Gram+ pathogens [5-II, 1011, 14, 24, 30, 31, 32, 57, 59-IV, 63-64-65, $67,66-74,75,76-77,78-79,82,88]$ were used.

\subsubsection{Definition of a new intramammary infection}

A quarter was considered infected if the same bacterial species was isolated in two (or more) consecutive or duplicate samples. A new IMI occurring during the dry period was declared when a pathogen, not found at drying-off, was found at calving. This definition includes two different quarter infection statuses at drying-off: (i) uninfected at drying-off and infected at calving and (ii) infected by a pathogen at drying-off and infected by another pathogen at calving. Some authors did not consider the second definition. They either did not observe such a new IMI (due to its very low frequency of occurrence) or they excluded all quarters already infected at drying-off from those at risk of a new IMI (most common).

\subsubsection{Calculation of the incidence of intramammary infections}

The incidence of IMI was the number of quarters contracting a new IMI during the dry period divided by the total number of quarters at risk of new IMI at drying-off. According to the definition of a new IMI (given above), the total number of quarters at risk could be different: all quarters versus 
only quarters uninfected at drying-off [1011, 34, 59-I, 59-IV, 80, 86]. In some papers, the incidence was directly provided. For others [14, 22, 48, 71, 83], calculations were made by reviewers. In each study of type $1 \mathrm{a}$ and $1 \mathrm{~b}$ (Fig. 1), the incidence in untreated quarters was compared to the incidence in treated quarters. In each study of type $2 \mathrm{a}$ and $2 \mathrm{~b}$ (Fig. 1), the incidence in cows under selective DCT or DQT was compared to the incidence in cows under blanket DCT. The significance of the difference in incidence between groups was assessed by a $\chi^{2}$ test, when it was feasible and not already provided by the authors of the original papers $[14,22,48,57,58,66-$ $74,67,71,78-79,82,83]$.

\subsection{Meta-analysis procedure}

The relative risk of new IMI (the incidence in untreated quarters versus the incidence in treated quarters) was summarised by a meta-analysis. The general variancebased method described by [60] was used. A summary estimate of the relative risk $\left(R R_{S}\right)$ was determined for all pathogens and also by pathogen type. The formulae for meta-analysis were the following:

$$
\begin{aligned}
& \ln R R_{s}=\frac{\sum_{i}\left(w_{i} \times \ln R R_{i}\right)}{\sum_{i} w_{i}} C I=e^{R R \pm 1.96} \sqrt{\frac{1}{\sum_{i} w_{i}}} \\
& w_{i}=\frac{1}{\operatorname{var}_{i}} \quad \operatorname{var}_{i}=\frac{\left(U T_{i}+T_{i}\right) \times N N I_{i}}{U T_{i} \times T_{i} \times N I_{i}} \\
& R R_{i}=\frac{I U T_{i}}{I T_{i}}
\end{aligned}
$$

where $R R_{s}$ is the summary estimate of the relative risk of new IMI (incidence in untreated quarters versus incidence in treated quarters), $w_{i}$ is the weight assigned to the $i$ th study, $R R_{i}$ is the relative risk of new IMI (incidence in untreated quarters versus incidence in treated quarters) in the $i$ th study, $C I$ are the limits of the $95 \%$ confidence interval of the summary estimate of the rel- ative risk of new IMI, $\operatorname{var}_{i}$ is the variance of the relative risk of new IMI in the $i$ th study, $U T_{i}$ is the total number of quarters at risk among untreated quarters in the $i$ th study, $T_{i}$ is the total number of quarters at risk among treated quarters in the $i$ th study, $N N I_{i}$ is the total number of quarters not contracting a new IMI among both treated and untreated quarters in the $i$ th study, $N I_{i}$ is the total number of quarters contracting a new IMI among both treated and untreated quarters in the $i$ th study, $I U T_{i}$ is the incidence in untreated quarters (in $\%$ of quarters at risk) in the $i$ th study, $I T_{i}$ is the incidence in treated quarters (in \% of quarters at risk) in the $i$ th study.

In order to assess the relevance of the summary estimates of the relative risk, the $Q$ parameter was calculated and compared to a $\chi^{2}$ distribution, with a number of degrees of freedom equal to the number of studies minus 1 [60]. This test of homogeneity checks if all studied samples can be assumed to come from the same meta-population. $Q$ was calculated as:

$$
Q=\sum_{i}\left(w_{i}\left(R R_{s}-R R_{i}\right)^{2}\right) .
$$

In case of heterogeneity, as an attempt to partially explain the deviation, a metaregression was done [29]. The model was:

$$
\begin{aligned}
Q_{i}= & \beta_{0}+\beta_{1} Y E A R_{i}+\beta_{2} B A C T_{i}+\beta_{3} D C T_{i} \\
& +\beta_{4} P_{R E V_{i}}+\beta_{5} \text { Staph }+\varepsilon
\end{aligned}
$$

where $Q_{i}$ is the weighted difference between the summary estimate of the relative risk and the relative risk in the $i$ th study, $\beta_{0}$ is the intercept, $\beta_{1} Y E A R_{i}$ is the year of publication in the $i$ th study (after versus before 1985), $\beta_{2} B A C T_{i}$ is the assessment of the microbiological procedures in the $i$ th study (one sample versus more than 1 ), $\beta_{3} D C T_{i}$ is the DCT used in the $i$ th study (Gram+ alone versus Gram+ and Gram- activity spectrum), $\beta_{4} P R E V_{i}$ is the prevalence at dryingoff in the $i$ th study (less versus more than $25 \%$ of infected quarters), $\beta_{5} \operatorname{Staph}_{i}$ is the 


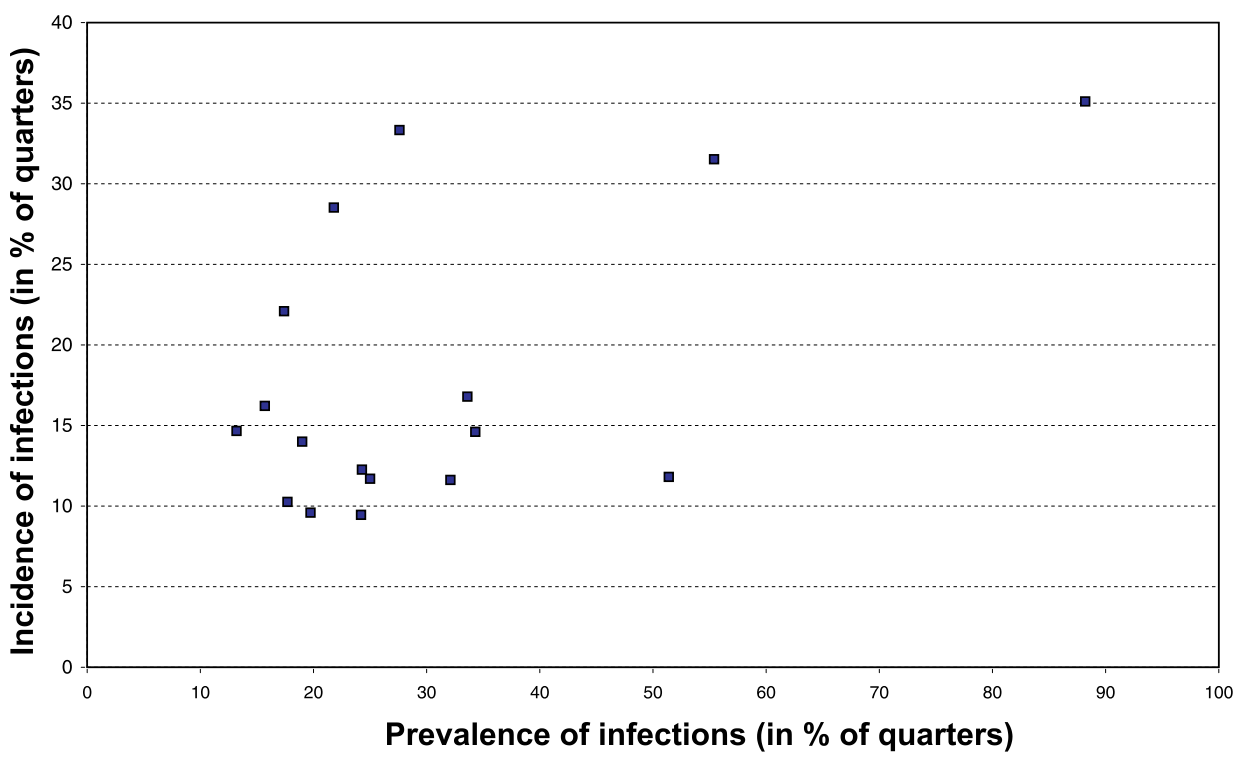

Figure 2. Incidence in untreated cows during the dry period (in \% of quarters at risk) and prevalence at drying-off in untreated cows (in \% of quarters at risk).

proportion of quarters infected by staphylococci (CPS and CNS) at drying-off in the $i$ th study (less versus more than $15 \%$ of infected quarters), $\varepsilon$ is the residual error term.

Cut-off values were selected according to the distribution of the variables. If a variable was significantly associated with the $Q_{i}(P$ value $<0.20)$, a secondary meta-analysis was implemented, after stratification of the studies according to the levels of this variable. To calculate weighted means and meta-analytic $R R_{s}$, studies could only be considered once when several DCT were used in the same study. Therefore, two summary estimates of the relative risk were provided. To obtain the first one, DCT which minimised the difference between untreated and treated quarters, and for the second one, DCT which maximised this difference, were retained. Neither meta-analysis nor weighted mean calculations were deemed relevant when less than four studies could be included.

\section{RESULTS}

\subsection{Incidence following random omission of antibiotic treatment}

\subsubsection{Comparison between untreated and antibiotic-treated quarters (type $1 a$ and $1 b$ designs)}

\subsubsection{Cumulated incidence of intramammary infections}

In untreated quarters at risk, 6.5 to $33.3 \%$ contracted a new IMI in studies of type 1a, and 11.6 to $35.1 \%$ in studies of type $1 \mathrm{~b}$ (Tab. III), and the incidence averaged $12.8 \%$ (weighted mean). The incidence was not correlated to the prevalence of IMI in untreated quarters at drying-off (Spearman correlation coefficient $=0.25, P$ value $=$ 0.33) (Fig. 2).

In antibiotic-treated quarters at risk, 0 to $28.6 \%$ contracted a new IMI in studies of type $1 \mathrm{a}$ and 2.3 to $37.2 \%$ in studies of type $1 \mathrm{~b}$ 

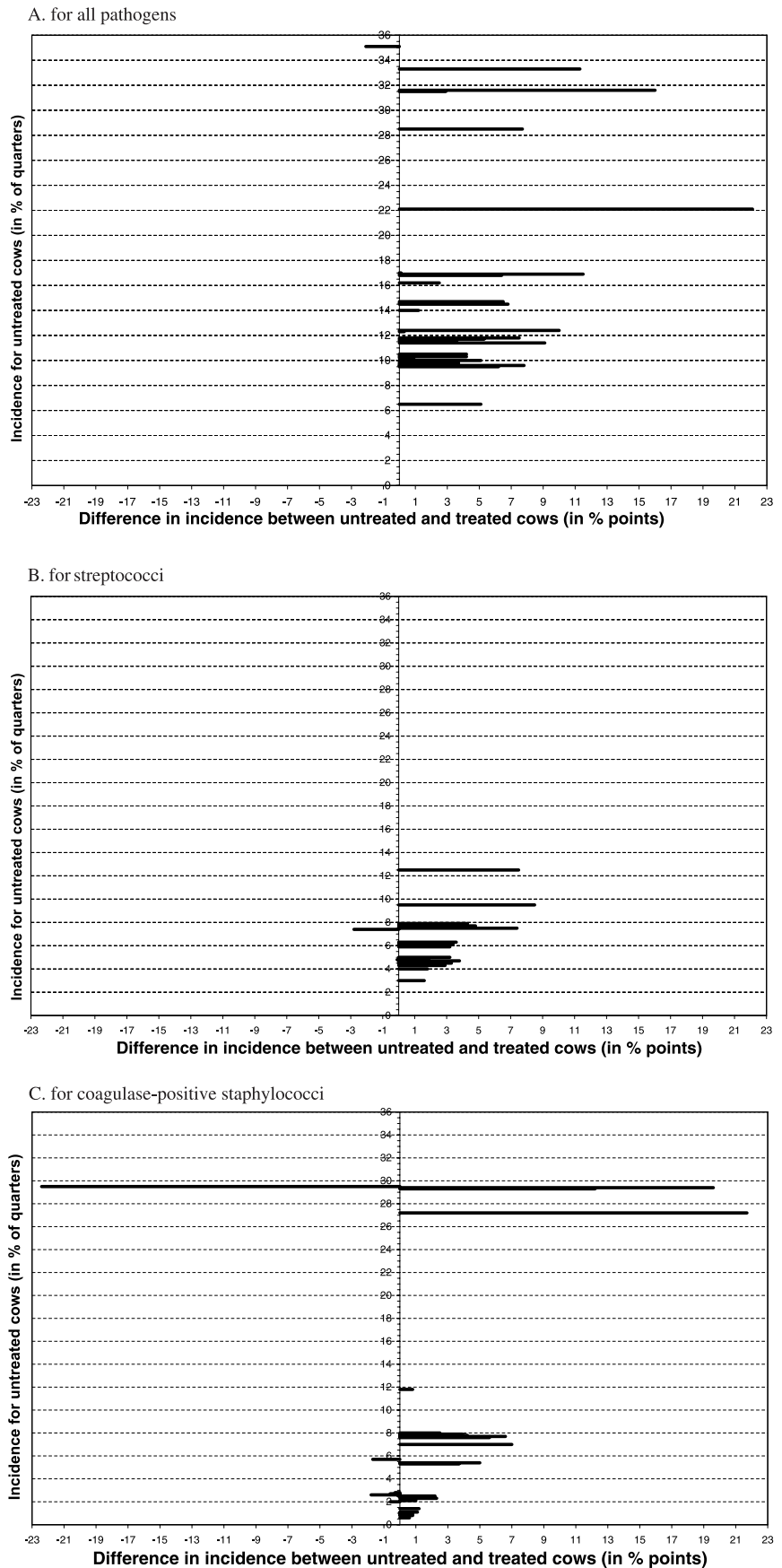

Figure 3. Incidence in untreated cows during the dry period (in $\%$ of quarters at risk) and difference in incidence between untreated and treated cows (untreated minus treated cows) (in \% points). (A) For all pathogens, (B) for streptococci, (C) for coagulase-positive staphylococci. 
(Tab. III), and the incidence averaged 6.6 or $8.0 \%$ (weighted means), according to the DCT used (respectively, the most and the less effective).

A higher incidence was systematically observed in untreated than in treated quarters, except in [71] (Fig. 3). The difference (incidence in untreated quarters minus incidence in treated quarters) varied from -2.1 to $+22.1 \%$ points (Fig. 3 ), being significant in 15 studies out of 25 (Tab. III). Intrastudy, the relative risk ranged from 0.94 to 5.69 (Tab. IV) and the summary $R R_{s}$ were 1.54 and 1.94 (Tab. V), depending on the DCT (respectively, the most and the less effective). The differences were heterogeneous between studies. None of the factors tested by the meta-regression established a possible origin for the heterogeneity of the studies. No secondary meta-analysis was done.

\subsubsection{Incidence by pathogens}

New IMI were mainly due to streptococci and CPS. In $50 \%$ of the studies, each of these pathogens represented more than $35 \%$ of new IMI (Tab. III).

\subsection{Streptococci}

In untreated quarters at risk, 4.0 to $12.5 \%$ contracted a new IMI due to streptococci in studies of type $1 \mathrm{a}$ and 3.0 to $9.5 \%$ in studies of type $1 \mathrm{~b}$ (Tab. III), and the incidence averaged $5.9 \%$ (weighted mean).

In antibiotic-treated quarters at risk, 0.0 to $10.2 \%$ contracted a new IMI in studies of type $1 \mathrm{a}$ and 1.0 to $2.8 \%$ in studies of type $1 \mathrm{~b}$ (Tab. III), and the incidence averaged 1.9 or $2.7 \%$ (weighted means), according to the DCT used (respectively, the most and the less effective).

A higher incidence was systematically observed in untreated than in treated quarters in all studies, except in [14, 83] (Fig. 3). The difference (incidence in untreated quarters minus incidence in treated quarters) varied from -2.8 to $+8.5 \%$ points (Fig. 3 ), being significant in half of the studies (Tab. III).
Intra-study, the relative risk ranged from 0.75 to 10.00 (Tab. IV) and the estimates of $R R_{s}$ were 2.32 and 3.15 (Tab. V), depending on the DCT used. None of the factors tested by the meta-regression established a possible origin for the heterogeneity between the studies.

\subsection{Coagulase-positive staphylococci}

In untreated quarters at risk, 0.8 to $29.3 \%$ contracted a new IMI due to CPS in studies of type $1 \mathrm{a}$ and 0.6 to $11.8 \%$ in studies of type $1 \mathrm{~b}$ (Tab. III), and the incidence averaged $4.8 \%$ (weighted mean).

In antibiotic-treated quarters at risk, 0.0 to $51.7 \%$ contracted a new IMI in studies of type $1 \mathrm{a}$ and 0.0 to $11.0 \%$ in studies of type $1 \mathrm{~b}$ (Tab. III), and the incidence averaged 1.9 to $3.0 \%$ (weighted means), according to the DCT used.

A higher incidence was observed in untreated than in treated quarters in the majority of the studies (15 among 18) (Fig. 3). The difference (incidence in untreated quarters minus incidence in treated quarters) varied from -22.4 to $+21.7 \%$ points (Fig. 3), being significant in only five studies (Tab. III). Intra-study, the relative risk ranged from 0.56 to 18.63 (Tab. IV) and the $R R_{s}$ were 1.34 and 3.04 (Tab. V), depending on the DCT used. None of the factors tested by the meta-regression established a possible origin for the heterogeneity between the studies.

\subsection{Coagulase-negative staphylococci}

Only five studies [14, 30, 34, 71, 88] reported the specific incidence of CNS IMI (Tab. III). In untreated quarters at risk, 4.3 to $13.5 \%$ contracted a new IMI in studies of type $1 \mathrm{a}$ and 1.1 to $6.4 \%$ in studies of type $1 \mathrm{~b}$ (Tab. III), and the incidence averaged $5.6 \%$ (weighted mean).

In antibiotic-treated quarters at risk, 1.3 to $12.9 \%$ contracted a new IMI in studies of type $1 \mathrm{a}$ and 0.2 to $14.9 \%$ in studies of 
Table IV. Relative risk of new intramammary infections during the dry-period by pathogen type (incidence in untreated quarters versus incidence in treated quarters).

\begin{tabular}{|c|c|c|c|c|c|c|}
\hline \multirow[b]{2}{*}{ Reference $^{\mathrm{a}}$} & \multirow[b]{2}{*}{ No. ${ }^{b}$} & \multicolumn{5}{|c|}{ Relative risk of new intramammary infections ${ }^{c}$} \\
\hline & & $\begin{array}{c}\text { All } \\
\text { pathogens }\end{array}$ & Streptococci & $\begin{array}{l}\text { Coagulase positive } \\
\text { staphylococci }\end{array}$ & $\begin{array}{l}\text { Coagulase negative } \\
\text { staphylococci }\end{array}$ & Coliform \\
\hline \multicolumn{7}{|l|}{ Type 1a } \\
\hline \multirow[t]{2}{*}{ [76-77] } & 1 & 2.87 & 2.96 & 3.32 & & \\
\hline & 2 & 5.69 & 2.33 & $\begin{array}{c}18.63 \\
4.94\end{array}$ & & \\
\hline [22] \# \| & & 1.82 & 1.81 & 11.38 & & 0.96 \\
\hline [32] & & 1.79 & 2.72 & & & \\
\hline$[75]$ & & 4.50 & 1.62 & & & \\
\hline$[66-74] \#$ & & 1.33 & 1.72 & & & \\
\hline [31] NSA & & 1.22 & 3.71 & 0.82 & & \\
\hline \multirow[t]{4}{*}{ [82] \# } & 1 & 1.09 & 1.59 & 0.59 & & \\
\hline & 2 & 1.66 & 2.45 & 0.80 & & \\
\hline & 3 & 1.47 & 1.50 & 0.91 & & \\
\hline & 4 & 1.68 & 1.88 & 0.95 & & \\
\hline \multirow[t]{4}{*}{ [24] NSA } & $\begin{array}{l}1 \\
2\end{array}$ & & & & & \\
\hline & 3 & 1.62 & 2.42 & & & 0.89 \\
\hline & 4 & 1.34 & 2.10 & & & 1.39 \\
\hline & 5 & 2.12 & 2.59 & & & 1.49 \\
\hline \multirow[t]{2}{*}{ [57] \# } & 1 & 1.84 & & 1.95 & & \\
\hline & 2 & 1.62 & & 1.45 & & \\
\hline [58] \# & & & & 2.16 & & \\
\hline [78-79]\# & & & 2.50 & & & 0.50 \\
\hline \multirow[t]{3}{*}{ [30] } & 1 & 1.61 & 1.65 & 0 & 1.10 & 0.55 \\
\hline & 2 & 3.17 & 3.46 & 0 & 5.19 & 0 \\
\hline & 3 & 1.01 & 6.05 & 0 & 0.53 & 1.01 \\
\hline \multirow[t]{2}{*}{ [14] ॥ \# } & 1 & 1.10 & 0.75 & 3.73 & 0.61 & \\
\hline & 2 & 2.04 & 0 & 7.38 & 0.42 & \\
\hline \multirow[t]{3}{*}{ [80] } & 1 & & & 1.70 & & \\
\hline & 2 & & & 3.02 & & \\
\hline & 3 & & & 0.56 & & \\
\hline [34] & & 1.37 & 4.08 & 1.88 & 1.11 & \\
\hline$[5-\mathrm{I}]$ & & 0 & & 0 & & 0.98 \\
\hline$[5-\mathrm{II}]$ & & 2.75 & & 6.32 & & 0 \\
\hline [83] II \# & & 5.00 & & 0 & & \\
\hline \multicolumn{7}{|l|}{ Type 1b } \\
\hline [59-I] QT & & 1.18 & 2.22 & 1.08 & & \\
\hline [59-IV] $1 / 2 \mathrm{~T}$ & & 1.02 & 1.70 & 0.76 & & \\
\hline [48] QT II \# & & 1.46 & & & & \\
\hline [71] $1 / 2 \mathrm{~T} \| \#$ & & 0.94 & & 0 & 0.43 & \\
\hline [88] QT & & 5.42 & 10.00 & 0 & 6.00 & 1.00 \\
\hline
\end{tabular}

${ }^{a}$ QT: per cows, quarters were randomly allocated to treated/untreated group; $1 / 2 \mathrm{~T}$ : the same half udder was assigned to a group of treated/untreated quarters; \#: statistical analysis done by reviewers; II: incidence of new intramammary infections during the dry period calculated by reviewers; NSA: no statistical analysis could have been done; Type 1a: antibiotic treatment was randomly applied at the cow level; Type 1b: antibiotic treatment was randomly applied at the quarter level.

b Number of the dry cow treatment used (see Tab. II).

${ }^{c}$ Relative risk of new intramammary infections during the dry period: incidence of intramammary infections during the dry period in untreated quarters versus incidence in treated quarters. 
Table V. Summary estimate, confidence interval and test for homogeneity of the relative risk of new intramammary infections during the dry period (incidence in untreated quarters versus incidence in treated quarters) from meta-analysis.

\begin{tabular}{|c|c|c|c|c|c|c|c|}
\hline \multirow{2}{*}{ Pathogen type } & \multirow{2}{*}{ Reference } & \multicolumn{3}{|c|}{$\begin{array}{l}\text { Minimal RR of new } \\
\text { intramammary infections }\end{array}$} & \multicolumn{3}{|c|}{$\begin{array}{l}\text { Maximal RR of new } \\
\text { intramammary infections }\end{array}$} \\
\hline & & $R R_{S}{ }^{\mathrm{a}}$ & $\mathrm{CI}^{\mathrm{b}}$ & $Q^{c}$ & $R R_{S}{ }^{\mathrm{a}}$ & $\mathrm{CI}^{\mathrm{b}}$ & $Q^{c}$ \\
\hline All pathogens & $\begin{array}{c}\text { [5-II, 14, 22, 24, 30-31-32, } \\
34,48,57,59-I, 59-I V, ~ 71, \\
66-74,76-77,82,83,88]\end{array}$ & 1.54 & $1.42 ; 1.67]$ & $98.14(\mathrm{~s})$ & 1.94 & {$[1.78 ; 2.13]$} & $95.97(\mathrm{~s})$ \\
\hline Streptococci & $\begin{array}{l}{[14,22,24,30,31,34,59-\mathrm{I}} \\
\text { 59-IV, 76-77, 78-79, 82, 88] }\end{array}$ & 2.32 & $1.98 ; 2.72]$ & $46.05(\mathrm{~s})$ & 3.15 & {$[2.63 ; 3.78]$} & $28.38(\mathrm{~s})$ \\
\hline $\begin{array}{l}\text { Coagulase positive } \\
\text { staphylococci }\end{array}$ & $\begin{array}{c}{[5-\mathrm{II}, 14,22,31,34,57,58} \\
\text { 59-I, 59-IV, 67, 76-77, 80, 82] }\end{array}$ & 1.34 & $1.10 ; 1.64]$ & $75.14(\mathrm{~s})$ & 3.04 & {$[2.42 ; 3.81]$} & $93.41(\mathrm{~s})$ \\
\hline $\begin{array}{l}\text { Coagulase negative } \\
\text { staphylococci }\end{array}$ & {$[14,30,34,71,88]$} & 0.83 & $0.61 ; 1.14]$ & $54.43(\mathrm{~s})$ & 1.12 & {$[0.80 ; 1.57]$} & $17.90(\mathrm{~s})$ \\
\hline Coliform & {$[5-\mathrm{I}, 22,24,30,78-79,88]$} & 0.86 & $.62 ; 1.20]$ & $1.55(\mathrm{~ns})$ & 0.96 & {$[0.70 ; 1.34]$} & $2.75(\mathbf{n s})$ \\
\hline
\end{tabular}

${ }^{a} R R_{S}$ : summary estimate of the relative risk of new intramammary infections during the dry period (incidence in untreated quarters versus incidence in treated quarters).

${ }^{b}$ CI: $95 \%$ confidence interval of the summary estimate of the relative risk of new intramammary infections during the dry period.

${ }^{c}$ Q: test for homogeneity, (s): heterogeneous, (ns): homogeneous.

type $1 \mathrm{~b}$ (Tab. III), and the incidence averaged 5.1 or $6.7 \%$ (weighted means), according to the DCT used.

Three studies reported a higher incidence of CNS IMI in untreated than in treated quarters and two reported a lower incidence. The difference (incidence in untreated quarters minus incidence in treated quarters) varied from -8.5 to $+5.5 \%$ points, being significant in one of the studies (Tab. III). Intrastudy, the relative risk ranged from 0.42 to 6.00 (Tab. IV) and the $R R_{s}$ were 0.83 and 1.12 (Tab. V), depending on the DCT used. None of the factors tested by the metaregression established a possible origin for the heterogeneity between the studies.

\subsection{Coliforms}

A small number of studies (8 studies) reported new Coliform IMI. In the others, the authors either did not observe Coliform IMI or only focused on Gram+ pathogens.
In untreated quarters at risk, 0.0 to $5.6 \%$ contracted a new IMI in studies of type 1a and $0.8 \%$ in studies of type $1 \mathrm{~b}$ (Tab. III), and the incidence averaged $1.2 \%$ (weighted mean).

In antibiotic-treated quarters at risk, 0.0 to $11.0 \%$ contracted a new IMI in studies of type $1 \mathrm{a}$ and $0.8 \%$ in studies of type $1 \mathrm{~b}$ (Tab. III), and the incidence averaged 1.2 to $1.3 \%$ (weighted means), according to the DCT used.

No clear trend was observed for the difference in incidence between the untreated and the treated quarters, which varied from -2.8 to $+8.5 \%$ points, being significant in half of the studies (Tab. III). Intra-study, the relative risk ranged from 0.50 to 1.49 (Tab. IV) and the $R R_{s}$ were 0.86 and 0.96 (Tab. V), depending on the DCT used. Differences were homogeneous between the studies. 
Table VI. Incidence of intramammary infections during the dry period and relative risk of new intramammary infections during the dry period in groups of quarters untreated, antibiotic treated, or with a teat sealer application.

\begin{tabular}{lcccccc}
\hline \multirow{2}{*}{ Reference $^{\mathrm{a}}$} & \multicolumn{3}{c}{ Incidence of intramammary infections ${ }^{\mathrm{b}}$} & & \multicolumn{2}{c}{ Relative risk of new intramammary infections } \\
\cline { 2 - 3 } & Teat sealer & $\begin{array}{c}\text { Antibiotic } \\
\text { treated }\end{array}$ & Untreated & & $\begin{array}{c}\text { Teat sealer versus } \\
\text { antibiotic treated }\end{array}$ & $\begin{array}{c}\text { Teat sealer versus } \\
\text { untreated }\end{array}$ \\
\hline$[88]$ QT II \# & 2.4 & $2.3(-0.1 \mathrm{NS})$ & $12.7\left(+10.3^{* * *}\right)$ & & 1.04 & 0.19 \\
{$[35]$ II \# } & 36.2 & $42.6\left(+6.4^{* *}\right)$ & & & 0.85 & 0.29 \\
{$[3-4]$} & 3.4 & & $11.6\left(+8.2^{* * *}\right)$ & & & \\
\hline
\end{tabular}

${ }^{\text {a }}$ QT: per cows, quarters were randomly allocated to the antibiotic treated group, the untreated group or the group with a teat sealer application; \#: statistical analysis done by reviewers; II: incidence of new intramammary infections during the dry period calculated by reviewers.

${ }^{\mathrm{b}}$ Incidence of intramammary infections during the dry period (in percentage of quarters): number of quarters newly infected during the dry period divided by the total number of quarters at risk of new intramammary infections during the dry period, in the groups with a teat sealer application, the antibiotic treated group, or the untreated group.

${ }^{c}$ Relative risk of new intramammary infections during the dry period: ratio of incidence in quarters with a teat sealer application versus antibiotic treated or untreated quarters.

$* \mathrm{Sp}<0.05 ; * * \mathrm{Sp}<0.01 ; * * * \mathrm{Sp}<0.001$; NS: not significant.

\subsubsection{Comparison of application of a teat sealer to either the absence of antibiotic treatment or blanket dry cow treatment}

No study on external teat sealer was eligible for this meta-analysis and only 3 eligible studies $[3-4,35,88]$ dealt with an internal teat sealer made of bismuth subnitrate in an oily basis. Study samples were restricted to cows, or quarters presumed not infected or infected at a low prevalence level (see Tab. I). In the selected studies, the incidence in the untreated quarters was quite similar to the studies of types $1 \mathrm{a}$ and $1 \mathrm{~b}$ presented above, and ibid. in the treated quarters.

When a teat sealer was applied, from 2.4 to $36.2 \%$ of the quarters at risk contracted a new IMI (Tab. VI). New IMI were mainly due to CNS (above $50 \%$ of new IMI). The incidence was significantly higher in untreated quarters compared to quarters with an application of a teat sealer. Moreover, the incidence was lower (significantly in [35], and not significantly in [88]) in quarters with application of a teat sealer than in antibiotic-treated quarters (Tab. VI). Intra-study, the relative risks were 0.85 or 1.04 and 0.19 or 0.29 , for quarters with an application of a teat sealer versus, respectively, antibiotictreated and untreated quarters (Tab. VI). Given the small number of studies, no weighted mean, nor $R R_{s}$ were calculated.

\subsection{Incidence following selective omission of antibiotic treatment}

In these studies, the DCT was not randomly applied to groups derived from the overall population, but only to a sub-population of selected cows or quarters (Fig. 1). The selection criteria used (Tab. VII) indicate that the cows left untreated were probably uninfected or only infected with a low probability. In the group of cows under blanket DCT, from 2.6 to $21.9 \%$ of quarters at risk contracted a new IMI and the average incidence was $6.5 \%$ (weighted mean). This level was not discrepant with the results of studies previously analysed (Sect. 2.1).

In cows under selective DCT, from 3.9 to $28.7 \%$ of the quarters at risk contracted a new IMI, and the average incidence was $9.9 \%$ (weighted mean), when 27.1 to $57.1 \%$ 


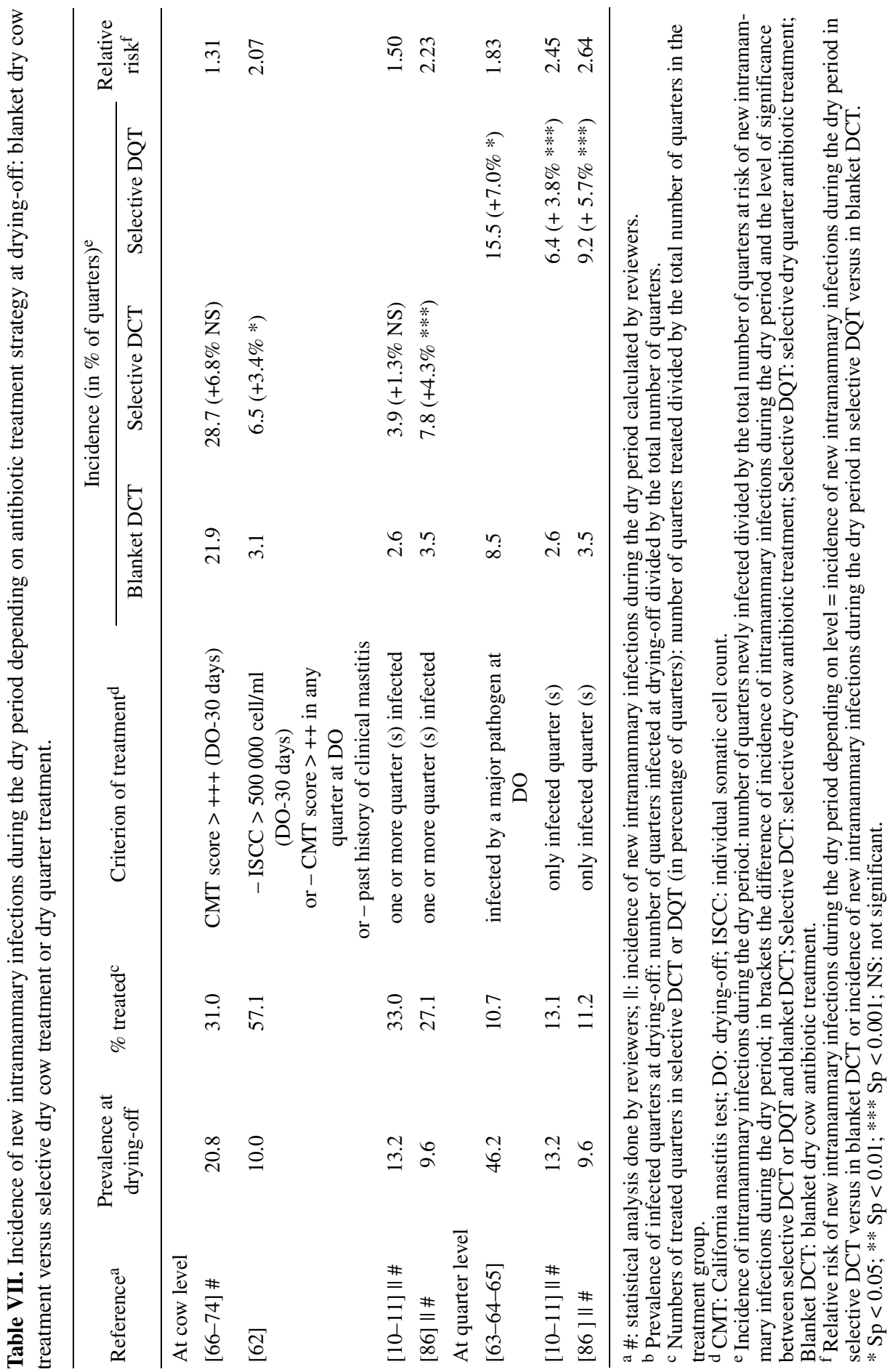


of the quarters were treated (Tab. VII). The difference in incidence (the incidence in cows under selective DCT minus the incidence in cows under blanket DCT) ranged from +1.3 to $+6.8 \%$ points, and was significant in half of the studies. Intra-study, the relative risk ranged from 1.31 to 2.23 (Tab. VII) and the summary $R R_{S}$ (selective DCT versus blanket DCT) was $1.71(\mathrm{CI}=$ [1.37; 2.14], and $Q=3.49$, i.e. absence of heterogeneity).

In quarters under selective DQT, from 6.4 to $15.5 \%$ of the quarters at risk contracted a new IMI (Tab. VII), when only around $10 \%$ of the quarters were treated. The difference in incidence (incidence in cows under selective DQT minus incidence in cows under blanket DCT) ranged from +3.8 to $+7.0 \%$ (Tab. VII). All studies demonstrated a significant difference. Neither weighted mean, nor $R R_{s}$ were calculated from the three selected studies, but the intra-study relative risks varied from 1.83 to 2.64 (Tab. VII). When compared to selective DCT, the selective DQT was found associated with a higher incidence of IMI $(\mathrm{RR}=1.64$ in $[9,10]$ and $1.18-\mathrm{NS}-$ in $[86])$.

\section{DISCUSSION}

This study was aimed at summarising the comparative incidence of spontaneously occurring IMI during the dry period, without or with DCT (random or selective omission, without or with application of a teat sealer). New IMI were mainly due to streptococci and CPS. A higher incidence of streptococcal and CPS IMI was observed in untreated than in treated quarters. No clear trend was observed for the difference in incidence between untreated and treated quarters for CNS or Coliform IMI. The same result was for the difference in incidence observed between selective DCT and blanket DCT. The incidence of IMI under selective DQT was higher than under blanket DCT. The incidence of IMI after the application of a teat sealer was lower than in untreated quarters and not different than treated quarters. However, wide variation was present between the 30 studies (results from 1966 to 2003 in 10 different countries) reported in the 36 selected papers here considered for review and meta-analytic calculation. Only studies based on a comparative study design including an untreated group were included in the analysis, and therefore, a quite large number of papers comparing alternative DCT without any untreated group were not considered here.

Both study populations and study designs differed between the selected papers. Consequently, the incidence of IMI in untreated quarters varied widely (from 6.5 to $35.1 \%$ ), as well as the type of pathogens responsible for these IMI. This may possibly explain that, assuming the existence of additional differences in risk factors and in the type of DCT, the test for homogeneity of differences in relative risks between studies concluded to heterogeneity. The meta-regression procedure implemented here was intended to identify some factors of heterogeneity, but remained unsuccessful. This means that sample characteristics and material descriptions in studies were insufficient to cluster studies or that other variation factors of incidence of IMI were probably involved. Nevertheless, we provided a summary estimate of the relative risk in order to have an approximate value for the central trend, when the number of studies was not deemed too small. Of course, such summary estimates should only be extrapolated with caution to a particular population. In the last decades, the distribution of streptococci has changed considerably. In the older studies, Streptococcus agalactiae was frequently observed, while in the more recent studies, Streptococcus agalactiae was less frequent or absent $[7,69]$. However, the effect of this evolution on the variation of incidence of IMI could not be assessed, because of the low number of new IMI due to Streptococcus agalactiae.

Some methodological origins for possible differences between studies were reported in Section 2.1.2, although the selected papers 
did not all report the same characteristics. For example, the microbiological procedure (especially duplicate sample, volume of milk spread, storage of samples, culture medium used, etc.) was different among studies. However, the resulting differences in sensitivity (ability to avoid false negatives) can be assumed to affect to a larger extent the measurement of the incidence, but this effect was neutralised when calculating the intra-study relative risk for untreated versus treated quarters, and thus the summary estimate of relative risk provided by our calculations.

Many managerial risk factors of new IMI were evidenced in previous studies: method of drying-off, housing condition, teat dipping at drying-off, vitamin and mineral supplement, ... (for review, see [17, 18, 21, 89]). However, when thinking to omission or substitutes to DCT, the fact that the technique of intramammary administration is suspected to be a risky procedure should be taken into account. The incidence of IMI during the dry period was found higher in cows with a placebo than in untreated or treated cows: $12.6 \%$ versus 5.9 in untreated cows or $9.9 \%$ in treated cows [9], and $19.4 \%$ versus $14.4 \%$ in treated cows [16]. Around $60 \%$ of new IMI were due to staphylococci in [16], which are naturally present in the microflora of the teat skin [15]. Nocardia asteroides mastitis cases were reported after DCT [23, 81], but no link with DCT could be clearly made. The insertion of a pathogen can also occur with an internal teat sealer $[3-4,35,88]$. No or little information about herd management and quality in implementation of intramammary DCT administration were available in the papers selected and, therefore, no further analysis on their impact could be done here. Under field conditions of DCT (or teat sealer) use, less precautions than those taken in the included studies are implemented (no careful disinfection for aseptically sampling before infusion), and then the risk of new IMI could be higher than that reported here.
To summarise, the central trend for the overall effectiveness of DCT was estimated at 33 to $53 \%$ relative reduction of the incidence of IMI at the quarter level during the dry period. The effectiveness was found quite different according to pathogens (Tab. III). The highest value (57 to $68 \%$ ) was reached for streptococcal IMI, and a quite interesting one (23 to 67\%) existed for CPS IMI. Protection of DCT against CNS and Coliforms seemed of limited magnitude or not effective, in terms of a central trend, given our analysis.

There are two periods of elevated risk of new IMI during the dry period: the first weeks after drying-off during involution of the udder [50] and the weeks preceding calving during colostrogenesis [13, 53, 85]. Most of the DCT used did no longer prevent new IMI during the latter period of elevated risk, especially for long dry periods $[5,58$, $62]$. As a result, at the end of the dry period, untreated and treated cows would stay at the same risk of new IMI. All DCT used in the selected studies were effective against Gram+ bacteria, but most of them were a priori not effective against Gram- bacteria. Thus, no clear conclusion may be drawn for these latter bacteria. By contrast, the limited or nonexistent effect against CNS IMI suggests that these IMI occur very late in the dry period, just before calving as well as in early lactation [43, 52, 54, for review see 55] or another hypothesis is that the resistant CNS strain possibly infected the udder [40].

From the selected studies, the application of an internal teat sealer was able to prevent new IMI, quite possibly better than DCT. However, this result should only be extrapolated with caution, due to the small number of eligible comparative approaches, which were conducted in a low risk context, except [35].

In this paper, selective DCT, applied in a subpopulation of likely uninfected or few infected cows, was found associated with a variable level of elevated incidence of IMI during the dry period, compared to blanket DCT. In counterpart, the proportion of 
treated cows can become very low in some herds, depending on the prevalence of IMI at drying-off and on the criterion used to select the cows eligible for DCT. Bacteriological examination was used to determine which cows were left untreated in most of the selected studies. Under field conditions, this procedure generates additional costs and other difficulties such as need for aseptical sampling and transportation after preservation/freezing of the samples. Other cowside tests could be used, but they have a lower sensitivity and could result in more misclassifications $[1,56,61]$. The availability of the cow-level SCC information in most dairy herds favours its use to select, much cheaper, the cows for DCT. However, an informative value of criteria based on SCC are usually lower than bacteriological examinations $^{3}[20,37]$. This leads to the treatment of some false positive (uninfected) cows and to leave untreated some false negative (infected) cows.

Selective DQT, with a decision rule at the quarter level, was found associated with a quite higher risk of new IMI, than selective DCT, especially in [10-11]. However, the proportion of treated quarters in herds decreased approximately 4-fold between DCT and DQT. In fact, uninfected quarters in infected cows are more at risk of new IMI than in uninfected cows, as already reported $[50,82]$. This could be due to an individual cow susceptibility $[1,2,6]$ or to a cross-contamination within the same cow [2,89]. The question of the respective impact of these two mechanisms should be further investigated. Moreover, selective DQT needs a method to identify the infected or presumed infected quarters, and, under practical conditions, the availability of cow-level SCC in most dairy herds favours the implementation of selective DCT rather than selective DQT.

\footnotetext{
3 Hogeveen H., Sampimon O.C., Relationship between individual somatic cell count and bacteriology: a detailed study on a low bulk milk somatic cell count farm, Proc. SVEPM, Chester, United Kingdom, 1997, pp. 258-267.
}

Finally, in the selected studies, selective DCT or DQT was in fact only implemented with a curative objective, and no study was aimed at exploring its relevance for cows exposed to a higher risk of occurrence. More generally, the curative use of DCT in truly infected cows is more acceptable by consumers and society, and particularly when the molecules used were not recently developed for human medicine. The preventive use of DCT is much more challenged $[3,4,8,10]$ and can only be supported by a high risk of occurrence of new IMI during the first weeks of the dry period. In herds with a low risk of new IMI during the dry period, the use of a teat sealer or selective DCT thus seems to be an alternative. More knowledge and operational tools for risk ex-ante assessment are therefore needed.

The evaluation of the health benefits and the economical profitability of, for instance, selective DCT versus blanket DCT, cannot be done solely knowing the difference in incidence during the dry period. Indeed, reportedly, $50 \%$ of the IMI occurring during the dry period persist until the following lactation, and, among these persisting IMI, $50 \%$ become clinical during the following lactation [50]. Furthermore, bacteria present during the dry period could have a deleterious effect on the subsequent lactation [28, 54]. Thus, the number of clinical cases in early lactation due to new IMI occurring during the dry period could be slightly different between selective DCT and blanket DCT [11]. This mid-term effect, as well as a quite long term effect resulting from the secondary IMI cases, induced in other cows during their lactation, should be considered in economic decision support elements. Moreover, decision should also integrate the curative effect of DCT which depends on the prevalence of IMI at drying-off.

To conclude, based on the available literature, blanket DCT was effective in limiting the incidence of IMI occurring during the dry period by around minus $45 \%$, for a level of about $13 \%$ in incidence without 
DCT, as a central trend over the reviewed studies. When the risk of new IMI is high, the blanket DCT has a favourable impact on the number of new IMI, but this impact, despite of a real effectiveness of the therapy, becomes limited to null when the risk without DCT is very low. In such situations, the use of a teat sealer or a selective DCT should be considered after adequate economic assessment.

\section{ACKNOWLEDGEMENTS}

The authors would like to thank the reviewers for their very useful suggestions to improve the initial manuscript.

\section{REFERENCES}

[1] Andrews R.J., Kitchen B.J., Kwee W.S., Duncalfe F., Relationship between individual cow somatic cell counts and the mastitis infection status of the udder, Aust. J. Dairy Technol. 38 (1983) 71-74.

[2] Barkema H.W., Schukken Y.H., Lam T.J.G.M., Galligan D.T., Beiboer M.L., Brand A., Estimation of interdependence among quarters of the bovine udder with subclinical mastitis and implications for analysis, J. Dairy Sci. 80 (1997) 1592-1599.

[3] Berry E.A., Hillerton J.E., The effect of an intramammary teat seal on new intramammary infections, J. Dairy Sci. 85 (2002) 25122520.

[4] Berry E.A., Hillerton J.E., Field evaluation and economic analysis of the use of Orbeseal ${ }^{\mathrm{TM}}$ during the dry period, Cattle Practice 10 (2002) 197-201.

[5] Berry E.A., Hillerton J.E., The effect of selective dry cow treatment on new intramammary infections, J. Dairy Sci. 85 (2002) 112-121.

[6] Berry E.A., Johnston W.T., Hillerton J.E., Prophylactic effects of two selective dry cow strategies accounting for interdependence of quarter, J. Dairy Sci. 86 (2003) 3912-3919.

[7] Bradley A.J., Bovine mastitis: an evolving disease, Vet. J. 164 (2002) 116-128.

[8] Bradley J.M., Noone P., Townsend D.E., Grubb W.B., Methicillin-resistant Staphylococcus aureus in a London hospital, Lancet 1 (1985) 1493-1495.
[9] Bratlie O., Dry cow therapy, Vet. Rec. 93 (1973) 430-431.

[10] Browning J.W., Mein G.A., Barton M., Nicholls T.J., Brightling P., Effects of antibiotic therapy at drying off on mastitis in the dry period and early lactation, Aust. Vet. J. 67 (1990) 440-442.

[11] Browning J.W., Mein G.A., Brightling P., Nicholls T.J., Barton M., Strategies for mastitis control: dry cow therapy and culling, Aust. Vet. J. 71 (1994) 179-183.

[12] Buelow K.L., Thomas C.B., Goodger W.J., Nordlund K.V., Collins M.T., Effect of milk sample collection strategy on the sensitivity and specificity of bacteriologic culture and somatic cell count for detection of Staphylococcus aureus intramammary infection in dairy cattle, Prev. Vet. Med. 26 (1996) 1-8.

[13] Cousins C.L., Higgs T.M., Jackson E.R., Neave F.K., Dodd F.H., Susceptibility of the bovine udder to bacterial infection in the dry period, J. Dairy Res. 47 (1980) 11-18.

[14] Cummins K.A., McCaskey T.A., Multiple infusions of cloxacillin for treatment of mastitis during the dry period, J. Dairy Sci. 70 (1987) 2658-2665.

[15] Devriese L.A., De Keyser H., Prevalence of different species of coagulase-negative staphylococci on teats and in milk samples from dairy cows, J. Dairy Sci. 47 (1980) 155-158.

[16] Dingwell R.T., Duffield T.F., Leslie K.E., Keefe G.P., DesCoteaux L., Kelton D.F., Lissemore K.D., Schukken Y.H., Dick P., Bagg R., The efficacy of intramammary tilmicosin at drying-off, and other risk factors for the prevention of new intramammary infections during the dry period, J. Dairy Sci. 85 (2002) 3250-3259.

[17] Dingwell R.T., Kelton D.F., Leslie K.E., Management of the dry cow in control in peripartum disease and mastitis, Vet. Clin. North Am. Food Anim. Pract. 19 (2003) 235-265.

[18] Dingwell R.T., Leslie K.E., Schukken Y.H., Sargeant J.M., Timms L.L., Duffield T.F., Keefe G.P., Kelton D.F., Lissemore K.D., Conklin J., Association of cow and quarterlevel factors at drying-off with new intramammary infections during the dry period, Prev. Vet. Med. 63 (2004) 75-89.

[19] Dodd F.H., Westgarth D.R., Neave F.K., Kingwill R.G., Mastitis - the strategy of control, J. Dairy Sci. 52 (1969) 689-695.

[20] Dohoo I.R., Leslie K.E., Evaluation of changes in somatic cell counts as indicators of new intramammary infections, Prev. Vet. Med. 10 (1991) 225-237. 
A. Robert et al.

[21] Eberhart R.J., Management of dry cows to reduce mastitis, J. Dairy Sci. 69 (1986) 17211732.

[22] Eberhart R.J., Buckalew J.M., Evaluation of a hygiene and dry period therapy program for mastitis control, J. Dairy Sci. 55 (1972) 16831691.

[23] Ferns L., Dohoo I.R., Donald A., A case-control study of Nocardia mastitis in Nova Scotia dairy herds, Can. Vet. J. 32 (1991) 673-677.

[24] Funk D.A., Freeman A.E., Berger P.J., Environmental and physiological factors affecting mastitis at drying off and postcalving, J. Dairy Sci. 65 (1982) 1258-1268

[25] Gill R., Howard W.H., Leslie K.E., Lissemore K., Economics of mastitis control, J. Dairy Sci. 73 (1990) 3340-3348.

[26] Godden S., Rapnicki P., Stewart S., Fetrow J., Johnson A., Bey R., Farnsworth R., Effectiveness of an internal teat seal in the prevention of new intramammary infections during the dry and early-lactation periods in dairy cows when used with a dry cow intramammary antibiotic, J. Dairy Sci. 86 (2003) 3899-3911.

[27] Godinho K.S., Bramley A.J., The efficacy of teat dips of differing persistence on teat skin in preventing intramammary infection by Streptococcus uberis and Escherichia coli in dry cows, Br. Vet. J. 136 (1980) 574-579.

[28] Green M.J., Green L.E., Medley G.F., Schukken Y.H., Bradley A.J., Influence of dry period bacterial intramammary infection on clinical mastitis in dairy cows, J. Dairy Sci. 85 (2002) 2589-2599.

[29] Greenland S., Quantitative methods in the review of epidemiologic literature, Epidemiol. Rev. 9 (1987) 1-30.

[30] Harmon R.J., Crist W.L., Hemken R.W., Langlois B.E., Prevalence of minor udder pathogens after intramammary dry treatment, J. Dairy Sci. 69 (1986) 843-849.

[31] Heald C.W., Jones G.M., Nickerson S., Bibb T.L., Mastitis control by penicillin and novobiocin at drying-off, Can. Vet. J. 18 (1977) $171-180$

[32] Hill G.N., Keefe T.J., Clinical efficacy of benzathine cloxacillin in dry-cow mastitis treatment, Mod. Vet. Pract. 55 (1974) 843-846.

[33] Hillerton J.E., Bramley A.J., Staker R.T., McKinnon C.H., Patterns of intramammary infection and clinical mastitis over a 5 year period in a closely monitored herd applying mastitis control measures, J. Dairy Res. 62 (1995) 39-50.
[34] Hogan J.S., Smith K.L., Todhunter D.A., Schoenberger P.S., Efficacy of dry cow therapy and a Propionibacterum acnes product in herds with low somatic cell count, J. Dairy Sci. 77 (1994) 3331-3337.

[35] Huxley J.N., Green M.J., Green L.E., Bradley A.J., Evaluation of the efficacy of an internal teat sealer during the dry period, J. Dairy Sci. 85 (2002) 551-561.

[36] Kingwill R.G., Neave F.K., Dodd F.H., Griffin T.K., Westgarth D.R., Wilson C.D., The effect of a mastitis control system on levels of subclinical and clinical mastitis in two years, Vet. Rec. 87 (1970) 94-100.

[37] Kristula M.A., Galligan D.T., Curtis C.R., Bartholomew R.C., Evaluation of a dairy improvement association test to report chronic intramammary infections in dairy cattle, Prev. Vet. Med. 14 (1992) 251-258

[38] Loosmore R.M., Howell D., Adams A.D., Barnett D.N., Barr T.F.F., Drying-off therapy for bovine mastitis: a comparative field trial, Vet. Rec. 83 (1968) 358-360.

[39] Luedecke L.O., Forster T.L., Williams K., Hillers J.K., Effect of freezing and storage at $-20{ }^{\circ} \mathrm{C}$ on survival of mastitis pathogens, $\mathrm{J}$. Dairy Sci. 55 (1972) 417-418.

[40] Makovec J.A., Ruegg P.L., Antimicrobial resistance of bacteria isolated from dairy cow milk samples submitted for bacterial culture: 8905 samples (1994-2001), JAVMA 222 (2003) 1582-1589.

[41] Makovec J.A., Ruegg P.L., Characteristics of milk samples submitted for microbiological examination in Wisconsin from 1994 to 2001, J. Dairy Res. 17 (2003) 3466-3472.

[42] Matthews K.R., Harmon R.J., Langlois B.E., Crist W.L., Hemken R.W., Use of latex teat dip with germicide during the prepartum period, J. Dairy Sci. 71 (1988) 1940-1946.

[43] Matthews K.R., Harmon R.J., Langlois B.E., Prevalence of Staphylococcus species during the periparturient period in primiparous and multiparous cows, J. Dairy Sci. 75 (1992) 1835-1839.

[44] McArthur B.J., Fairchild T.P., Moore J.J., Efficacy of a latex teat sealer, J. Dairy Sci. 67 (1984) 1331-1335.

[45] Meaney W.J., Dry period teat seal, Vet. Rec. 99 (1976) 30.

[46] Meaney W.J., Effect of a dry period teat seal on bovine udder infection, Irish J. Agric. Res. 16 (1977) 293-299. 
[47] Meaney B., Ryan M.P., Flynn J., Hill C., Ross R.P., The use of a non-antibiotic teat sealer in combination with a food-grade bacteriocin, lacticin 3147 , for mastitis prevention in nonlactating dairy cows, Cattle Practice 7 (1999) 215-219.

[48] Morse G.E., Prophylactic and therapeutic benefits of dry cow therapy in mastitis control, Ann. Bull. - Inter. Dairy Fed. 85 (1975) 358361 .

[49] Natzke R.P., Therapy: one component in a mastitis control system, J. Dairy Sci. 54 (1971) 1895-1901.

[50] Neave F.K., Dodd F.H., Henriques E., Udder infections in the "dry period", J. Dairy Res. 17 (1950) 37-49.

[51] Neave F.K., Dodd F.H., Kingwill R.G., Westgarth D.R., Control of mastitis in the dairy herd by hygiene and management, J. Dairy Sci. 52 (1969) 696-707.

[52] Oliver S.P., Frequency of isolation of environmental mastitis-causing pathogens and incidence of new intramammary infection during the nonlactating period, Am. J. Vet. Res. 49 (1988) 1789-1793

[53] Oliver S.P., Mitchell B.A., Susceptibility of bovine mammary gland to infections during the dry period, J. Dairy Sci. 66 (1983) 11621166.

[54] Oliver S.P., Sordillo L.M., Udder health in the periparturient period, J. Dairy Sci. 71 (1988) 2584-2606.

[55] Oliver S.P., Jayarao B.M., Coagulase-negative staphylococcal intramammary infections in cows and heifers during the nonlactating and periparturient periods, J. Vet. Med. B 44 (1997) 355-363.

[56] Osteras O., Sandvik L., Aursjo J., Gjul G.G., Jorstad A., Assessment of strategy in selective dry cow therapy for mastitis control, J. Vet. Med. B 38 (1991) 513-522.

[57] Pankey J.W., Barker R.M., Twomey A., Duirs G., A note on effectiveness of dry cow therapy in New Zealand dairy herds, N. Z. Vet. J. 30 (1982) 50-52.

[58] Pankey J.W., Barkert R.M., Twomey A., Duirs G., Comparative efficacy of dry-cow treatment regimens against Staphylococcus aureus, N. Z. Vet. J. 30 (1982) 13-15.

[59] Pearson J.K.L., Wright C.L., Dry cow therapy as a means of controlling bovine mastitis, Vet. Rec. 84 (1969) 294-298.

[60] Petitti D.B., Meta-analysis decision analysis and cost-effectiveness analysis - Methods for quantitative synthesis in Medicine, Oxford University Press, Oxford, 1994.

[61] Poutrel B., Rainard P., California mastitis test guide of selective dry cow therapy, J. Dairy Sci. 64 (1981) 241-248.

[62] Rindsig R.B., Rodewald R.G., Smith A.R., Spahr S.L., Complete versus selective dry cow therapy for mastitis control, J. Dairy Sci. 61 (1978) 1483-1497.

[63] Robinson T.C., Jackson E.R., Maar A., Within herd comparison of teat dipping and dry therapy with only selective dry cow therapy in six herds, Vet. Rec. 112 (1983) 315-319.

[64] Robinson T.C., Jackson E.R., Marr A., Factors involved in the epidemiology and control of Streptococcus uberis and Coliform mastitis, Br. Vet. J. 141 (1985) 635-642.

[65] Robinson T.C., Jackson E.R., Marr A., Mastitis incidence in quarters with different infection status at drying off and calving in two treatment groups, Br. Vet. J. 144 (1988) 166173.

[66] Roguinsky M., Serieys F., Comparaison du traitement des infections mammaires au tarissement chez toutes les vaches ou chez les seules vaches infectées, Ann. Rech. Vet. 8 (1977) 327-331.

[67] Rosenzuaig A., Mayer E., Observations on the effect of treatment of cows at drying-off on the incidence of sub-clinical udder infection in two dairy herds, Refu. Vet. 27 (1970) 129138.

[68] Ryan M.P., Flynn J., Hill C., Ross R.P., Meaney W.J., The natural food grade inhibitor, lacticin 3147, reduced the incidence of mastitis after experimental challenge with Streptococcus dysgalactiae in nonlactating dairy cows, J. Dairy Sci. 82 (1999) 21082114.

[69] Schällibaum M., Mastitis pathogens isolated in Switzerland, 1987-1996, IDF Mastitis News Mastitis Newsletter 23 (1999) 14.

[70] Schukken Y.H., Smit J.A.H., Grommers F.J., Vandegeer D., Brand A., Effect of freezing on bacteriologic culturing of mastitis milk samples, J. Dairy Sci. 72 (1989) 1900-1906.

[71] Schukken Y.H., VanVliet J., VandeGeer D., Grommers F.J., A randomized blind trial on dry cow antibiotic infusion in a low somatic cell count herd, J. Dairy Sci. 76 (1993) 29252930

[72] Schultze W.D., Effects of a selective regimen of dry cow therapy on intramammary infection and on antibiotic sensitivity of surviving pathogens, J. Dairy Sci. 66 (1983) 892-903. 
[73] Schultze W.D., Control of new intramammary infection at calving by prepartum teat dipping, J. Dairy Sci. 68 (1985) 2094-2099.

[74] Serieys F., Roguinsky M., Comparative tests with dry cow therapy for some or all cows in a herd, Ann. Bull. - Inter. Dairy Fed. 85 (1975) 349-351.

[75] Sinkevich M.G., Barto P.B., Bush L.J., Wells M.E., Adams G.D., Effectiveness of antibiotic infusion at drying-off in preventing new mastitis infections in cows, Bovine Pract. 9 (1974) 43-46.

[76] Smith A., Neave F.K., Dodd F.H., Brander G.C., Methods of reducing the incidence of udder infection in dry cows, Vet. Rec. 79 (1966) 233-236.

[77] Smith A., Westgarth D.R., Jones M.R., Neave F.K., Dodd F.H., Brander G.C., Methods of reducing the incidence of udder infection in dry cows, Vet. Rec. 81 (1967) 504-510.

[78] Smith K.L., Todhunter D.A., Schoenberger P.S., Environmental mastitis: cause, prevalence, prevention, J. Dairy Sci. 68 (1985) 531553.

[79] Smith K.L., Todhunter D.A., Schoenberger P.S., Environmental pathogens and intramammary infection during the dry period, J. Dairy Sci. 68 (1985) 402-417.

[80] Soback S., Ziv G., Winkler M., Saran A., Systemic dry cow therapy - a preliminary report, J. Dairy Sci. 73 (1990) 661-666.

[81] Stark D.A., Anderson N.G., A case-control study of Nocardia mastitis in Ontario dairy herds, Can. Vet. J. 31 (1990) 197-201.
[82] Swenson G.H., Posology and field efficacy study with novobiocin for intramammary infusion in nonlactating dairy cows, Can. J. Comp. Med. 43 (1979) 440-447.

[83] Tarabla H., Canavesio V., Prevalence of intramammary infections by major pathogens at parturition in dairy cows after intramuscular antibiotic therapy at drying-off: a preliminary report, J. Dairy Res. 70 (2003) 233-235.

[84] Twomey D.P., Wheelock A.I., Flynn J., Meaney W.J., Hill C., Ross R.P., Protection against Staphylococcus aureus mastitis in dairy cows using a bismuth-based teat seal containing the bacteriocin, lacticin 3147, J. Dairy Sci. 83 (2000) 1981-1988.

[85] Ward G.E., Schultze L.H., Incidence and control of mastitis during the dry period, J. Dairy Sci. 57 (1974) 1341-1349.

[86] Williamson J.H., Woolford M.W., Day A.M., The prophylactic effect of a dry-cow antibiotic against Streptococcus uberis, N. Z. Vet. J. 43 (1995) 228-234.

[87] Wilson C.D., Mastitis control, Vet. Annu. 9 (1968) 61-68.

[88] Woolford M.W., Williamson J.H., Day A.M., Copeman P.J.A., The prophylactic effect of a teat sealer on bovine mastitis during the dry period and the following lactation, N. Z. Vet. J. 46 (1998) 12-19.

[89] Zadoks R.N., Allore H.G., Barkema H.W., Sampimon O.C., Wellenberg G.J., Gröhn Y.T., Schukken Y.H., Cow- and quarter-level risk factors for Streptococcus uberis and Staphylococcus aureus mastitis, J. Dairy Sci. 84 (1984) 2649-2663. 